\title{
秋田県民の環境 $\gamma$ 線被ばく線量
}

\author{
山下順助 ${ }^{* 1}$, 渡会二郎 ${ }^{* 2}$, 久松俊一 ${ }^{* 3}$ \\ ${ }^{* 1}$ 秋田大学医学部放射性同位元素センター, ${ }^{* 2}$ 放射線医学講座 \\ 010-8543 秋田市本道 1-1-1 \\ *3 (財) 環境科学技術研究所
}

039-3212 青森県上北郡六ヶ所村大字尾鮫字家ノ前 1-7

2001年3月14日 受理

\begin{abstract}
$\mathrm{NaI}(\mathrm{Tl})$ シンチレーションサーベイメータを用いて, 秋田県内の屋外舗装路面上207か所, 未舗装 地上 45 か所, 屋内コンクリート建築 9 か所, 木造家屋 9 か所に招ける環境 $\gamma$ 線量の測定を行った。実 測值からバックグラウンド（宇宙線およびサーベイメータの自己照射）を減じた值は，屋外舗装路

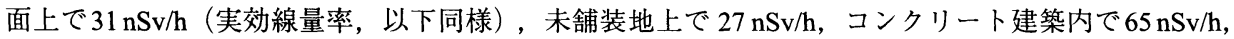

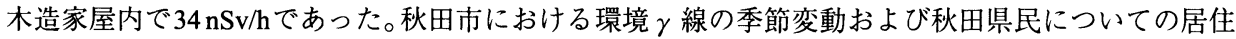
係数を考慮して, 県民一人当たりの年間被ばく線量は, 屋外で $0.03 \mathrm{mSv} / \mathrm{y}$, 屋内で $0.33 \mathrm{mSv} / \mathrm{y}$, 計 0.36 $\mathrm{mSv} / \mathrm{y}$ と推定された。
\end{abstract}

Key Words : environmental gamma-ray, $\mathrm{NaI}(\mathrm{Tl})$ scintillation surveymeter, Akita Prefecture

\section{1. はじめに}

近年，国内各地で環境 $\gamma$ 線量の測定が行わ れ，さまざまな知見が得られている1)-5)。秋田県 内の環境 $\gamma$ 線量に関しては阿部らの全国調査 の結果6) と著者らの調査結果7), 8) が報告されて いるが，阿部らの報告は 10 市町 76 地点の測定 結果であり, 著者らの報告も 10 市町 14 地点の 測定結果および玉川温泉という限られた地域 の測定值にすぎず，いずれも全県 69 市町村を網 羅したものではない。

現在の放射線防護基準では確率的影響（がん と遺伝的影響）に関してはしきい值がないと仮 定されているが, 実際の低線量域での線量 - 効 果関係は明らかになっていない9)。したがって 種々の自然放射線源からの被ばく線量をでき るだけ正確に推定することは，極低線量の放射 線被ばくのヒト集団への影響を解明するため の重要な基礎資料になると考えられる。

このような観点から, 著者らは秋田県という
限られた地域ではあるが，自然放射線源からの 秋田県民の被ばく線量を推定するため，秋田県 内69市町村におけるさまざまな場所での環境 $\gamma$ 線量の測定を行った。一般的に環境 $\gamma$ 線の測 定は人工物の影響をなるべく避けて行われる。 しかしながら，実際の生活場面では舗装路や家 屋などの人工物のある環境で過ごすことが多 いと考えられることから，都市の舗装面上での 測定を重視した。さらに，季節変動を初めとす る種々の因子を考慮して，県民の被ばく線量を 推定した。

\section{2. 調査方法}

\section{$2 \cdot 1$ 測定器と測定方法}

測定器には $\mathrm{NaI}(\mathrm{Tl})$ シンチレーションサーベ イメータ（ALOKA TCS-161）を使用した。本測 定器は $25.4 \mathrm{~mm} \phi \times 25.4 \mathrm{mmh}$ の $\mathrm{NaI}(\mathrm{Tl})$ シンチ レータを使用し， $0.1 \mathrm{nSv} / \mathrm{h}$ 以上の $\gamma$ 線線量率を 測定することができる。また，波高值ごとにス ペクトル - 線量変換演算子の重み付けを行っ 
てエネルギー補償を行い, $1 \mathrm{~cm}$ 線量当量率 $(\mathrm{Sv} /$ h）が直読できる機器である。本論文中の測定 值はすべて $1 \mathrm{~cm}$ 線量当量率で表している。

本測定器は (財) 放射線計測協会において, ${ }^{137} \mathrm{Cs}$ の $\gamma$ 線を $2,6,20 \mathrm{mSv} / \mathrm{h}$ の線量当量率で 標準照射することによって校正を行った。な お，放射線校正のできないレンジについては， パルス点検により表示値の確認を実施した。そ の後は, サーベイメータ付属のチェッキング ソースで適宜に指示值を読みとり，校正終了時 の値と変動がないことを確認してから測定に 供した。

測定に当たっては, サーベイメータの検出器 中心を地上 $1 \mathrm{~m}$ と, 電源を入れて 5 分間ウオー ミングアップしてから，30秒ごとに 15 回メー ター値を読みとり, その平均值を測定值とし た。なお，常に検出器中心を一定の高さに保つ ため，可搬型の木製スタンドを作成し，スタン ド上にサーベイメータを設置した。

\section{$2 \cdot 2$ 環境 $\gamma$ 線量の測定時期と測定場所}

環境 $\gamma$ 線の線量率測定は屋外と屋内に分け て行った。さらに, 屋外については, 舗装面と 未舗装面に分類し, 屋内は木造家屋と鉄筋コン クリート建築に分けて測定を行った。

以下に, 各地点での測定の詳細を述べる。

（1）屋外：舗装路面

秋田県内の全市町村である69市町村の舗装 路面上（各市町村 3 地点, 計 207 地点) におけ る測定は，1999年 8 月から 10 月にかけて降雨の ない日中に行った。

測定場所としては，各市町村の市町村役場， 郵便局, 鉄道の駅とし, 各施設の駐車場あるい は施設前の歩道上で測定した。なお，鉄道の駅 のない町村においては, 警察署, 交番等の警察 関係の施設とした。

69市町村の測定地点を Fig. 1 に示す。

(2) 屋外：未舗装地

2000年9月に秋田県内9市（Fig. 1）において， 各市 5 地点, 計 45 地点で測定を行った。測定は

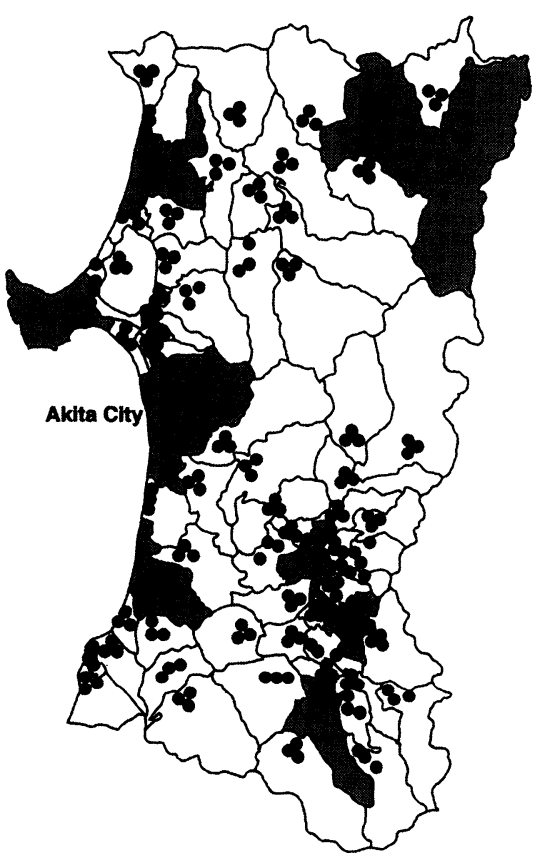

Fig. 1 Measurement sites on pavement in Akita Prefecture.

Shadows show cities where environmental $\gamma$-ray dose rates were measured on unpaved ground and indoors.

舖装路面の場合と同様に降雨のない日中に 行った。測定場所は公園が 2 地点, 学校の校庭 が 2 地点, 水田が 1 地点の計 5 地点であり,でき るだけ舗装路面上の測定地点に近いところと した。

（3）屋内：コンクリート建築

1999年 8月から 10月にかけて, 降雨のない日 中に県内 9市（Fig. 1）の各市役所（すべて鉄筋 コンクリート建築) の 1 階ホールで, 壁から $2 \mathrm{~m}$ 以上離れた地点における床上 $1 \mathrm{~m}$ の線量率を測 定した。

（4）屋内：木造家屋

同じく1999年 8 月から 10月にかけて, 各市役 所近隣の木造家屋から 1 軒を選択し, その 1 階 でコンクリート建築の場合と同様に測定した。

\section{$2 \cdot 3$ 季節変動}

環境 $\gamma$ 線線量率の季節変動を把握するため, 
屋内として秋田市内のコンクリート建築およ び木造家屋をそれぞれ 1 か所選択し，1999年 6 月から2000年 5 月まで毎月 1 回測定した。

屋外については, 秋田市郊外の休耕田に木製 スタンドを固定し，環境 $\gamma$ 線線量率を屋内と同 じ時期に毎月1回測定した。ただし，12月から3 月にかけては積雪の影響による变動を明らか にするため, 新たな降雪の都度, 積雪量と線量 率の測定を行った。また，冬季間の測定時は サーベイメータの保温と断熱に配慮し， $5{ }^{\circ} \mathrm{C}$ 以 下にならないようにして測定した。

\section{$2 \cdot 4$ サーベイメータのバックグラウンド}

環境 $\gamma$ 線線量率を正確に測定するためには, 用いた測定器のバックグラウンド補正が重要 である。バックグラウンドには，宇宙線とサー ベイメー夕構成材料中の天然放射性物質から の自己照射が含まれる。これらを補正するため に，大地からの $\gamma$ 線を無視できると考えられる 秋田沖約 $1 \mathrm{~km}$, 水深 $15 \mathrm{~m}$ の海上に強化プラス チック製の船を出し, 船上で $\gamma$ 線線量率を測定 した。測定は 2000 年 9 月に行い, 結果は $17 \pm$ $2 \mathrm{nSv} / \mathrm{h}$ であった。本論文中のデー夕はこの值を バックグラウンドとして差し引いてある。ただ し，宇宙線線量率の高度による変化については 考慮していない。

\section{3. 結果と考察}

\section{$3 \cdot 1$ 環境 $\gamma$ 線線量率の測定結果}

（1）屋外：舖装路面

秋田県内 69 市町村のそれぞれの平均値を Fig. 2 に, 全測定地点における線量率の度数分 布をFig. 3aに示す。秋田県には高放射能温泉の 玉川温泉があり, 線量率は $4 \mu \mathrm{Sv} / \mathrm{h}$ に達するが8), 今回の 69 市町村の市街地における測定では, こ のように高い場所は認められなかった。測定值 はお扮むね正規分布を示し，測定地点別の最大 值は森吉町の米内沢駅前広場で観測された $44 \mathrm{nSv} / \mathrm{h}$ であり，最小值は小坂町の小坂町役場 前歩道での $18 \mathrm{nSv} / \mathrm{h}$ であった。各市町村別の平

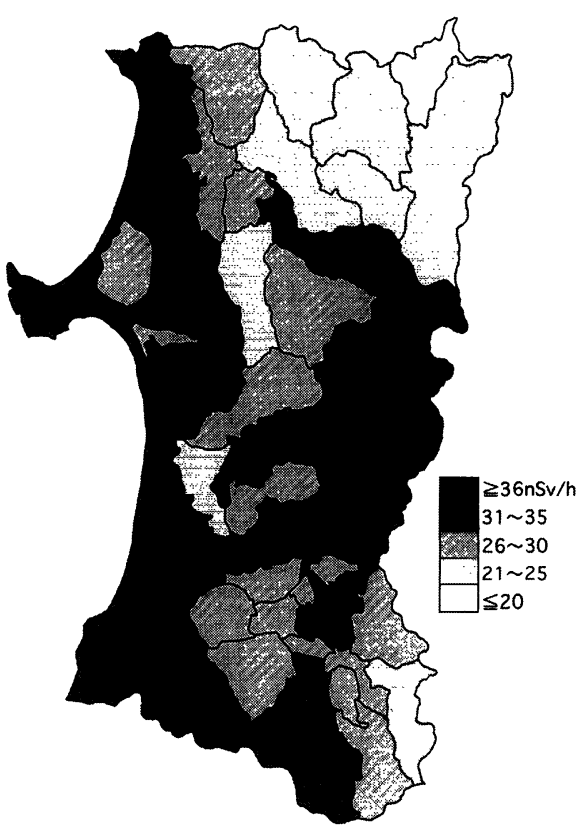

Fig. 2 Map of environmental $\gamma$-ray dose rate on pavement in Akita Prefecture.
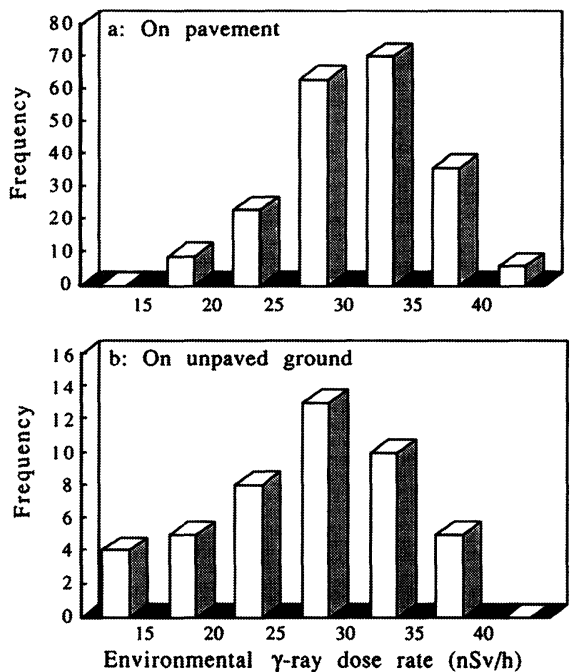

Fig. 3 Frequency distributions of the environmental $\gamma$-ray dose rates in Akita Prefecture. $\mathrm{a}:$ on pavement, $\mathrm{b}$ : on unpaved ground.

均では，最大值は金浦町の $38 \mathrm{nSv} / \mathrm{h}$ であり，最 小值は小坂町での $19 \mathrm{nSv} / \mathrm{h}$ であった。69市町村 すべての平均值は $31 \pm 6 \mathrm{nSv} / \mathrm{h}$ であった。Fig. 2 に 
示すように，秋田県北地方内陸部は，特に線量 率の低い地域（19-25nSv/h) であることが明ら かになった。

\section{（2）屋外：未舗装地}

秋田県内 9 市, 45 地点の線量率度数分布を Fig. 3bに示す。各市の平均では, 最大值は男鹿 市の $34 \mathrm{nSv} / \mathrm{h}$, 最小值は鹿角市の $15 \mathrm{nSv} / \mathrm{h}$ とな り, 9 市 45 地点の平均值は $27 \pm 8 \mathrm{nSv} / \mathrm{h}$ であっ た。

\section{（3）屋内}

県内 9 市の市役所内と近隣の木造家屋内で 測定した結果を屋外における測定結果とあわ せて Table 1 に示す。Table 1 から明らかなよう に, 環境 $\gamma$ 線線量率は, 屋外未舗装地上 $<$ 屋外 舗装路面上<屋内 (木造家屋) <屋内 (鉄筋コン クリート建築)であった。

屋内における環境 $\gamma$ 線線量率の内，県内 9 市 における木造家屋内の測定值に大きなばらつ きは見られず，おおむね屋外（舗装路面上）の 線量率に等しくなった。一方，コンクリート建 築に関しては，県内 9 市の市役所内における測 定值に大きな幅があったことから，建築材料あ るいは表面仕上げ材に含まれる自然放射性物 質に大きく依存するものと考えられたが，定量 的な関係を見いだすことができなかった。

\section{$3 \cdot 2$ 季節変動}

秋田市内における鉄筋コンクリート建築，木 造家屋および秋田市郊外の休耕田において毎 月 1 回環境 $\gamma$ 線線量率を測定した結果を Fig. 4

Table 1 Average of indoor and outdoor environmental $\gamma$-ray dose rates measured at 9 cities in Akita Prefecture

\begin{tabular}{|c|c|c|c|c|}
\hline \multirow{2}{*}{ Place } & \multicolumn{2}{|c|}{ Indoor } & \multicolumn{2}{|c|}{ Outdoor } \\
\hline & $\begin{array}{l}\text { Concrete } \\
\text { building }\end{array}$ & $\begin{array}{c}\text { Wooden } \\
\text { house }\end{array}$ & On pavement & $\begin{array}{l}\text { On unpaved } \\
\text { ground }\end{array}$ \\
\hline \multicolumn{5}{|l|}{ Dose rate } \\
\hline $\begin{array}{c} \pm S . D . \\
(\mathrm{nSv} / \mathrm{h})\end{array}$ & $65 \pm 20$ & $34 \pm 7$ & $32 \pm 7$ & $27 \pm 8$ \\
\hline
\end{tabular}

に示す。Fig. 4 に見られるように，屋内につい ては季節変動が見られなかったが, 屋外では降 雪時に線量率の大きな減少が認められた(Fig. 5)。積雪量の増加とともに線量率は減少し, 環 境 $\gamma$ 線線量率 $(\mathrm{nSv} / \mathrm{h})$ を $d$, 積雪量 $(\mathrm{cm})$ を $h$ と して, 最小二乗法により回帰式を求めたとこ 乃,

$$
d=23.7 \exp (-0.0234 h)
$$

がよく適合した $\left(r^{2}=0.66\right)$ 。なお, 積雪 $0 \mathrm{~cm}$ の 值は, 積雪のない 5 月から 11 月の平均值である。

\section{$3 \cdot 3$ 秋田県民に対する環境 $\gamma$ 線被ばく線 量の推定}

\section{（1）季節変動}

Fig. 4 に示すとおり屋内では季節変動は見ら れなかったが，Fig. 5 に示すように屋外におい ては，積雪による環境 $\gamma$ 線線量率の減少が確認 された。秋田地方気象台では, 県内を網羅して

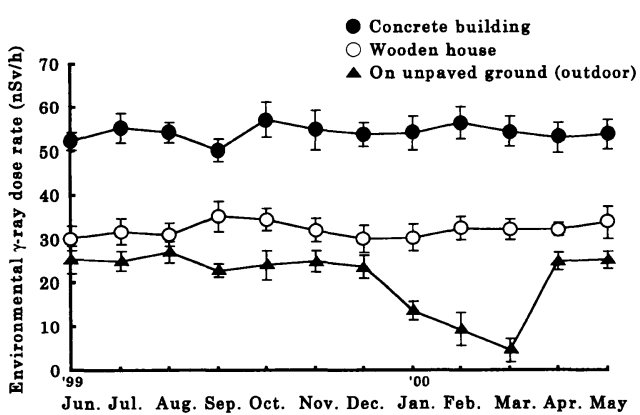

Fig. 4 Seasonal variation of environmental $\boldsymbol{\gamma}$-ray dose rates in Akita City.

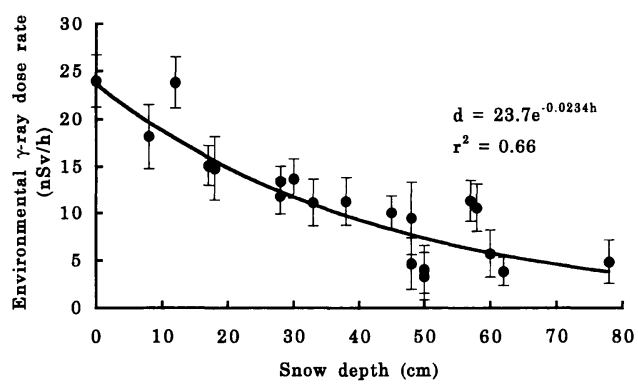

Fig. 5 Relationship between environmental $\gamma$-ray dose rate and snow depth. $d:$ dose rate, $h:$ snow depth. 
計 28 か所で毎日積雪量を測定している。その資 料10)-12)によって 1996年から 1998年の 3 年間に おける28か所の月別平均積雪量を求め, 降雪に よる線量率の減少を式(1)により月別に計算し た。

\section{（2）居住係数}

Table 1 に示すとおり, 環境 $\gamma$ 線線量率は屋外 と屋内で異なり，また，同じ屋外であっても舗 装路面上と未舗装地上では異なる。さらに，屋 内でも建築材料の相違によって線量は変化す る。これらを考慮して，それぞれの場所での被 ばく線量を求めるために，平均的秋田県民が 1 日24時間をどこに何時間滞在するかを推定し た。総務庁の社会生活基本調査報告13)を日本保 健物理学会報告書 ${ }^{14)}$ の方法で補正して秋田県民 の生活時間を推定すると，1日24時間のうち, 屋 内（住居, 一般施設, 学校, 仕事場) で過ごす 時間が21時間 12 分 $(88 \%)$, 屋外で過ごす時間が 2 時間 48 分 (12\%) となった。結果を Table 2 に

Table 2 Average of spent time on activities for the people of Akita Prefecture

\begin{tabular}{lll}
\hline \multicolumn{1}{c}{ Activity } & Indoor & Outdoor \\
\hline Sleep & $8: 03$ & 0 \\
Personal care & $1: 11$ & 0 \\
Meals & $1: 41$ & 0 \\
Commuting to and from school or work & 0 & $0: 23$ \\
Work & $2: 52$ & $1: 24$ \\
School work & $0: 20$ & $0: 01$ \\
House keeping & $1: 38$ & $0: 01$ \\
Nursing & $0: 03$ & 0 \\
Child care & $0: 10$ & $0: 01$ \\
Shopping & $0: 16$ & $0: 02$ \\
Moving & 0 & $0: 20$ \\
Watching TV, listening to radio, & $2: 30$ & 0 \\
reading newspapers or magazines & & \\
Rest and relaxation & $1: 22$ & 0 \\
Studies and researches & $0: 07$ & 0 \\
Hobbies and amusements & $0: 25$ & $0: 06$ \\
Sports & $0: 03$ & $0: 05$ \\
Social activities & $0: 01$ & $0: 02$ \\
Social life & $0: 23$ & 0 \\
Medical examination or treatment & $0: 07$ & 0 \\
Other activities & 0 & $0: 23$ \\
\hline \multicolumn{1}{c}{ Total time } & $21 \mathrm{~h} 12$ min & $2 \mathrm{~h} \mathrm{48} \mathrm{min}$ \\
\hline
\end{tabular}

示す。なお, 一般施設とは自分の住居, 学校, 仕事場以外の屋内を指す。

屋内で過ごす時間，21時間12分 (88\%) の内， 住居内で過ごす時間，16時間 38 分 (78\%) につ いては，木造家屋とコンクリート建築に配分し た。総務庁資料 15$)$ より秋田県の住宅の構造材料 別住宅戸数は，木製の建物が $90.8 \%$ ，コンク リート建築が $9.2 \%$ あっったので，この割合で 時間を比例配分した。家屋以外の一般施設，学 校および職場はすべてコンクリート建築とみ なした。したがって，木製の建物の中で過ごす 時間は，15時間 6 分 $(71 \%)$ ，コンクリート製の 建物の中で過ごす時間は 6 時間 6 分 $(29 \%)$ と なる。

屋外での行動の中で最も時間が長い仕事（1 時間 24分）について，農業および林業従事者は 未舗装地上で過ごすものとし，それ以外の職種 については舗装路面上で過ごすものとした。総 務庁資料 16$)$ から秋田県における農業および林 業従事者の人口比率を求めた結果 $7.8 \%$ であっ たので，未舗装地上で過ごす時間を7分間とし た。仕事以外の行動については推定の資料がな いためすべて舗装路面上で過ごすとみなした。 よって，舖装路面上で過ごす時間は 2 時間 41 分 $(96 \%)$ ，未舗装地上で過ごす時間は 0 時間 7 分 (4\%) となる。

以上をまとめた結果をTable 3 に示す。

（3）被ばく線量の推定

環境 $\gamma$ 線からの秋田県民の年間被ばく線量 は，上述のパラメータを用いて以下のとおり計 算した。ただし，舗装路面上の線量率は69市町 村の平均値を用い，未舗装地上の線量率は 9 市

Table 3 Average of spent time for various places for the people of Akita Prefecture

\begin{tabular}{cccccc}
\hline \multirow{2}{*}{ Place } & \multicolumn{2}{c}{ Indoor } & & \multicolumn{2}{c}{ Outdoor } \\
\cline { 2 - 3 } \cline { 5 - 6 } & $\begin{array}{c}\text { Concrete } \\
\text { building }\end{array}$ & $\begin{array}{c}\text { Wooden } \\
\text { house }\end{array}$ & & On & On unpaved \\
& pavement & ground \\
\hline \multirow{2}{*}{ Time } & $6 \mathrm{~h} 6 \mathrm{~min}$ & $15 \mathrm{~h} 6 \mathrm{~min}$ & & $2 \mathrm{~h} 41 \mathrm{~min}$ & $0 \mathrm{~h} 7 \mathrm{~min}$ \\
& $(29 \%)$ & $(71 \%)$ & & $(96 \%)$ & $(4 \%)$ \\
\hline
\end{tabular}


の平均値に〔69市町村の埔装路面上の平均値／ 9市の舗装路面上の平均値】を掛けた值を用い た。

(1) 屋内

屋内の線量率は木造家屋とコンクリート建 築に分け，以下のように計算した。

$D=d_{\mathrm{m}} o_{\mathrm{q}}(\mathrm{h} / \mathrm{y}) 10^{-6}$

ここで,

$D:$ 年間被ばく線量 $(\mathrm{mSv} / \mathrm{y})$

$d_{\mathrm{m}}$ : 線量率平均值 $(\mathrm{nSv} / \mathrm{h})$

$o_{\mathrm{q}}$ : 居住係数

$o_{\mathrm{q}}=$ 屋内生活時間比率 $\times$ 建築比率

屋内生活時間比率は 1 日のうち屋内 で過ごす時間の比率，建築比率は木 造またはコンクリート建築が家屋 全体に占める割合である。

$\mathrm{h} / \mathrm{y}:$ 時間/年

である。

(2) 屋外

屋外の線量率は舗装路面上と末舗装地上に 分け，雪による遮蔽を考慮して，以下のように 計算した。

$$
D=\frac{d_{\mathrm{m} O_{\mathrm{q}}}(\mathrm{h} / \mathrm{y}) 10^{-6}}{365} \sum_{i=1}^{12} s_{\mathrm{i}} n_{\mathrm{i}}
$$

ここで，

$D:$ 年間被ばく線量 $(\mathrm{mSv} / \mathrm{y})$

$d_{\mathrm{m}}:$ 線量率平均值 $(\mathrm{nSv} / \mathrm{h})$

$o_{\mathrm{q}}$ : 居住係数

1 日のうち，舖装路面上と未舗装地上で

過ごす時間のそれぞれの比率

$s_{\mathrm{i}}$ ：当該月の降雪による減少率

積雪量は県内の平均值を用いた。

$n_{\mathrm{i}}$ : 当該月の日数

である。以上の結果,

屋内（木造家屋内） $0.188 \mathrm{mSv} / \mathrm{y}$

屋内（コンクリート建築内） $0.146 \mathrm{mSv} / \mathrm{y}$

屋外（舗装路面上） $0.028 \mathrm{mSv} / \mathrm{y}$

屋外（未舗装地上） $0.001 \mathrm{mSv} / \mathrm{y}$ となり, 計 $0.363 \mathrm{mSv} / \mathrm{y}(1 \mathrm{~cm}$ 線量当量) と推定 された。
これらの結果に見られるように, 屋内線量率 の寄与が高く, 被ばく線量を正確に推定するに は，屋内の線量の把握が重要であることを示し ている。本調査では, 屋外に比べて屋内の測定 地点は少なく, 今後, 屋内の測定地点を増して より精度の高い推定を行う必要がある。

\section{4. 結 語}

秋田県民の自然放射線による被ばくを評価 するため, 環境 $\gamma$ 線線量率の県内分布を明らか にした。その結果と居住係数を合わせて，環境 $\gamma$ 線からの秋田県民一人当たりの年間被ばく 線量は, 屋外で $0.03 \mathrm{mSv} / \mathrm{y}$, 屋内で $0.33 \mathrm{mSv} / \mathrm{y}$, 計 $0.36 \mathrm{mSv} / \mathrm{y}$ と推定された。より正確な線量を 求めるためには, 屋内での線量率測定が重要で あることが示された。

本調査は, 1999年度文部省科学研究費補助金 奨励研究（B）の交付を受けて行った。本調査 の実施に当たり, 国立公衆衛生院池田耕一博士 から居住係数に関する資料の提供およびご助 言をいただきました。また, 測定器の特性・操 作について (株)ALOKA第 2 技術部技術第 4 課松 原昌平課長および同秋田出張所千葉 仁所長 からご助言をいただきました。記して深謝しま す。

\section{文献}

1) 平井英治, 玉利俊哉, 佐伯國夫, 岡村正紀, 松 岡信明, 高島良正, 松田廣繼, 廣 陽二, 大林 誠：電離箱検出器および $\mathrm{NaI}(\mathrm{Tl})$ シンチレーショ ン検出器を用いた福岡県の自然放射線量測定, Radioisotopes, 44, 846-855 (1995)

2) 松田秀晴: 東海地域の電車路線等における自然 空間放射線線量率の測定, Radioisotopes, 45, 125131 (1996)

3) 輪嶋隆博, 細川洋一郎, 竹腰光男, 藤田 智, 金 子昌幸, 安河内太郎：ポータブル型 $\gamma$ スペクト ロサーベイメータを用いた北海道の環境 $\gamma$ 線量 の調査, Radioisotopes, 46, 291-297 (1997)

4) 湊進:サーベイメータを携帯して記録した1 時間ごとの自然放射線量率, Radioisotopes, $\mathbf{4 8 ,}$ 327-333 (1999)

5) 湊 進, 種村誠太 : 名古屋市における地表 $\gamma$ 線線量率分布, Radioisotopes, 49, 217-222 (2000) 
6) 阿部史朗：わが国における自然の空間放射線分 布の測定，保健物理，17，169-193 (1982)

7) Zeng, X-S., Takizawa, Y. and Yamashita, J. : Investigation on environmental radiation dose in Akita prefecture and radio photoluminescence dosimeters used in environmental monitoring, J. Health Phys., 31, 435-441 (1996)

8) 山下順助, 滝澤行雄 : 秋田県玉川温泉の放射線 量率測定, 保健物理, 30, 239-242（1995）

9) 草間朋子 (編): “ICRP 1990年勧告 その要点と 考え方”, 日刊工業新聞社，東京 (1991)

10) 秋田県地方気象台：秋田県気象月報, 平成 8 年 1月～12月（1996）
11) 秋田県地方気象台: 秋田県気象月報, 平成 9 年 1月～12月（1997）

12) 秋田県地方気象台：秋田県気象月報, 平成10年 1 月 12月（1998）

13) 総務庁統計局 : 平成 8 年社会生活基本調査報告, 第 3 巻, 154-155 (1998)

14) 日本保健物理学会：ラドンの人体への影響評価 専門研究会報告書, 88-101（1998）

15) 総務庁統計局：第 49 回日本統計年鑑, 590 (2000)

16) 総務庁統計局：平成 7 年国勢調査報告書, 第 5 巻, 2-3 (1998)

\title{
Abstract
}

\section{Effective Dose Due to Environmental $\gamma$-Ray for the People of Akita Prefecture}

\author{
Junsuke YAMASHITA, Jiro WATARAI* and Shun'ichi HISAMATSU** \\ Radioisotope Research Center, *Department of Radiology, Akita University School of Medicine, \\ 1-1-1 Hondo, Akita-shi 010-8543, Japan \\ **Department of Radioecology, Institute for Environmental Sciences, \\ 1-7 Ienomae, Obuchi, Rokkasho-mura, Kamikita-gun, Aomori Pref. 039-3212, Japan
}

Environmental $\gamma$-ray doses were measured in Akita prefecture by a $\mathrm{NaI}(\mathrm{Tl})$ scintillation surveymeter. The numbers of measurement site were 207 on pavement, 45 on unpaved ground, nine in concrete buildings and nine in wooden houses. The results of measurements, which were subtracted for background (cosmic ray and self-irradiation of the surveymeter), were $31 \mathrm{nSv} / \mathrm{h}$ (effective dose rate) on pavement, $27 \mathrm{nSv} / \mathrm{h}$ on unpaved ground, $65 \mathrm{nSv} / \mathrm{h}$ in the concrete buildings and $34 \mathrm{nSv} / \mathrm{h}$ in the wooden houses. The effective dose rate due to environmental $\gamma$-ray for the people of Akita Prefecture was estimated taking into account of seasonal change of the dose rate at one site and occupancy factor in the prefecture. The outdoor and indoor dose rates were estimated to be $0.03 \mathrm{mSv} / \mathrm{y}$ and $0.33 \mathrm{mSv} / \mathrm{y}$, respectively. 